\title{
PEMENUHAN HAK-HAK KORBAN TINDAK KEJAHATAN PERKOSAAN DALAM MEWUJUDKAN KEADILAN RESTORATIF (Studi Kasus Di Pusat Pelayanan Terpadu Pemberdayaan Perempuan Dan Anak (P2TP2A) Kabupaten Malang)
}

\author{
${ }^{1}$ Erfaniah Zuhriah dan ${ }^{2}$ Himma Aliyah \\ 1,2Universitas Islam Negeri Maulan Malik Ibrahim Malang \\ ${ }^{1}$ erfaniahzuhriah@yahoo.com \\ 2himma.aliyahh@gmail.com
}

\begin{abstract}
This study focuses on how the process of assisting rehabilitation of rape victims and how P2TP2A Efforts in realizing Restorative Justice Against Rape Victims. This Research is categorized as (field research) type using descriptive qualitative approach. The results of this study that the process of assistance rehabilitation of rape victims conducted by P2TP2A, First Acceptance or submission of reports of sexual violence. Second, Identify and Register. Third, Assessment. Fourth, Rehabilitation Services, and Fifth, Advocacy and Legal Advocacy. Then do coaching Mental and Spiritual Guidance, Social and Psychological Development, and Skill / creativity development to rape victims. In an effort to realize restorative justice for rape victims, P2TP2A not only hold positive legal assistance as a benefit to the rape, but specifically the P2TP2A focused on the restoration of the rights of rape victims lost, in the prevention or preventive aspects, the community must have awareness Socially responsive gender, establishing an effective openness of communication patterns and the inculcation of spirituality values. Both aspects of Litigation, provide legal remedy to the victim and prosecute perpetrators punished weighing in accordance with applicable law. Third aspect of therapy, returning the victim to work or busyness within the limits of his ability and social role habits, so that victims are motivated in doing things that are productive and creative. And fourth, the rehabilitation aspect, as a effort to obtain maximum function and adjustment and to prepare victims physically, mentally and socially in the future.
\end{abstract}

Key Words: Restorative Justice; Rehabilitation; Rape Crime.

\section{Abstrak}

Penelitian ini memfokuskan pada bagaimana proses pendampingan rehabilitasi korban perkosaan dan pemenuhan hak-hak korban dalam mewujudkan keadilan restoratif di pusat pelayanan terpadu pemberdayaan perempuan dan anak (P2TP2A). Penelitian dikatagorikan sebagai jenis penelitian lapangan (field research) dengan menggunakan pendekatan kualitatif deskriptif. Hasil penelitian ini bahwa proses pendampingan rehabilitasi di P2TP2A, pertama penerimaan atau pengajuan laporan kekerasan seksual; kedua, Identifikasi dan Registrasi; ketiga, Assesmen (pemeriksaan); keempat, Pelayanan Rehabilitasi; dan kelima, Advokasi dan Pembelaan Hukum. Selanjutnya juga dilakukan Pembinaan Mental dan Spiritual, Pembinaan Sosial dan Psikologis, dan Pembinaan Keterampilan/kreatifitas terhadap korban perkosaan. Dalam mewujudkan keadilan restoratif, P2TP2A tidak hanya mangandalkan pendampingan hukum positif sebagai kemaslahatan pada korbaan perkosaan, akan tetapi secara khusus menitik beratkan pada pemulihan hak-hak korban perkosaan yang hilang dalam beberapa aspek. Pertama aspek pencegahan atau preventif; kedua aspek Litigasi; ketiga aspek terapi; dan keempat aspek rehabilitasi, sebagai usaha untuk memperoleh fungsi dan penyesuaian diri secara maksimal dalam kehidupannya dimasa mendatang.

Kata Kunci: Keadilan Restoratif; Rehabilitasi; Tindak Kejahatan Perkosaan. 


\section{PENDAHULUAN}

Kekerasan seksual adalah isu penting dan rumit dari seluruh peta kekerasan terhadap perempuan karena ada dimensi yang sangat khas bagi perempuan. Perempuan seringkali digambarkan sebagai pribadi yang lemah, penurut, tidak mampu memimpin dan sebagainya yang mengakibatkan anggapan perempuan menjadi nomor dua setelah laki-laki. Perempuan dengan kepribadian tersebut paling rentan menjadi obyek kekerasan, baik kekerasan berupa fisik maupun kekerasan berupa psikis. Kekerasan secara fisik maupun secara psikis yang paling sering terjadi dan sangat memperihatinkan yang dialami oleh perempuan adalah pemerkosaan.

Pemerkosaan sebagai salah satu bentuk kekerasan jelas dilakukan dengan adanya paksaan baik secara halus maupun kasar. Hal ini akan menimbulkan dampak psikologis bagi perempuan yang menjadi korban perkosaan tersebut. Hubungan seksual yang seharusnya dilakukan dengan adanya berbagai persiapan baik fisik maupun psikis dari pasangan yang akan melakukannya, dilakukan dengan cara tidak wajar, apalagi dengan cara paksaan yang akan menyebabkan gangguan pada perilaku seksual. Korban yang mengalami pemaksaan bersetubuh berupa kekerasan atau ancaman kekerasan. Ini berarti tidak ada persetujuan dari pihak korban mengenai niat tindakan perlakuan pelaku.

Hukum secara konseptual adalah piranti formal yang dapat diandalkan untuk penanganan kekerasan terhadap perempuan. Dalam konteks ini, hukum diharapkan dapat memberikaan keadilaan bagi korban kekerasan. Namun satu hal sejak awal harus diperhatikankan adalah bahwa diskursus soosiologi hukum mensinyalir bahwa hukum adalah satu bentuk formal dari tafsir sosial atas realitas (Aini, 2009). Dalam hukum positif di Indonesia kekerasan seksual dapat dijerat dengan pasal pencabulan 289 sampai dengan pasal 296 Kitab Undang-Undang Hukum Pidana (KUHP). Dalam hal ini terlihat jelas bahwa Negara telah mengatur secara tegas terhadap pelaku kekerasan seksual. Bahkan di dalam Al-Qur'an juga telah menegaskan tentang pelarangan melakukan kekerasan seksual terhadap wanita.

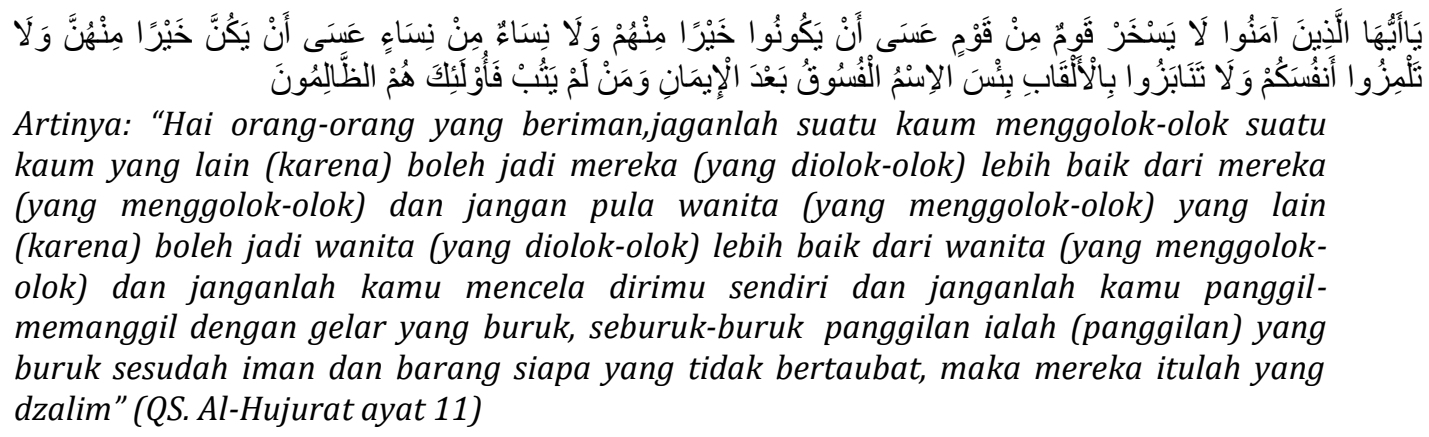
kaum yang lain (karena) boleh jadi mereka (yang diolok-olok) lebih baik dari mereka (yang menggolok-olok) dan jangan pula wanita (yang menggolok-olok) yang lain (karena) boleh jadi wanita (yang diolok-olok) lebih baik dari wanita (yang menggolokolok) dan janganlah kamu mencela dirimu sendiri dan janganlah kamu panggilmemanggil dengan gelar yang buruk, seburuk-buruk panggilan ialah (panggilan) yang buruk sesudah iman dan barang siapa yang tidak bertaubat, maka mereka itulah yang dzalim" (QS. Al-Hujurat ayat 11)

Pemerkosaan terhadap perempuaan yang menjadi korban inilah yang memunculkan terjadinya bias gender antara laki-laki dan perempuan. Menurut Fakih (1996), bias gender antara laki-laki dan perempuan tersebut termanifestasikan dalam berbagai bentuk ketidakadilan, antara lain : marginalisasi, subordinasi, dan pembentukan stereotip atau 
pelabelan negatif, kekerasan, beban kerja lebih banyak serta sosialisasi ideologi nilai peran gender.

Pemerkosaan terhadap perempuan memiliki dampak yang signifikan. Hasil penelitian mengungkap bahwa subjek mengalami pemerkosaan di latar belakangi oleh ketidak harmonisan keluarga, hubungan yang buruk antar peer group nya dan kurangnya perhatian orang tua. Terdapat temuan baru pada faktor yang mempengaruhi timbulnya dampak psikologis pemerkosaan yaitu pengalaman traumatik masa lampau yaitu pernah mengalami pelecehan seksual, dinamika keluarga, hubungan sosial dan perilaku negatif orang tua. Sedangkan dampak psikologis yang dialami oleh subjek adalah subjek mengalami kejadian traumatik yang dialami kembali oleh subjek, subjek menghindari hal yang berhubungan dengan trauma, Subjek mengalami peningkatan kesadaran dan dampak psikososial pasca pemerkosaan subjek memisahkan diri dari lingkungan (Sari, 2013). Usia-usia yang sangat rentan terhadap pemerkosaan adalah usia remaja, usia ini sangat rentan terhadap korban dan masa depan korban. Dari dampak yang ditimbulkannya tentunya korban usia ini mengalami ancaman terhadap keluarganya dan masa depan keluarganya ketika menikah kelak. Oleh karenanya, peneliti merasa tertarik untuk melakukan penelitian tentang pemenuhan hak-hak korban perkosaan dalam mewujudkan keadilan restoratif, degan fokus permasalahan peneliataian adalah bagaimana proses rehabilitasi dan pemenuhan hak korban dalam mewujudkan keadilan restoratif pada korban perkosaan.

Adapun penelitian terdahulu dari penelitian ini adalah sebagai berikut,

\begin{tabular}{|c|c|c|c|}
\hline NO & JDUL dan PENULIS & PERBEDAAN & PERSAMAAN \\
\hline 1 & $\begin{array}{l}\text { Islam dan Keadilan } \\
\text { Restoratif pada anak } \\
\text { yang berhadapan } \\
\text { dengan hukum ditulis } \\
\text { oleh Ifa Latifah } \\
\text { Fitriani, dan Tim } \\
\text { Kerja }\end{array}$ & $\begin{array}{l}\text { Penelitian terdahulu } \\
\text { dikatagorikan sebagai penelitian } \\
\text { Library research yang } \\
\text { memfokuskkan pada bagaimana } \\
\text { keadilan restoratif dalam } \\
\text { perspektif Islam. Urgensi dan } \\
\text { sisi-sisi maslahah keadialan } \\
\text { restoratif dalam penyelesaian } \\
\text { kasus anak berhadapan dengan } \\
\text { hukum. Sedangan penelitian } \\
\text { peneliti, lebih menitik beratkan } \\
\text { pada proses rehabilitasi dan } \\
\text { pemenuhan hak korban } \\
\text { perkosaan dalam mewujudkan } \\
\text { keadilan restoratif yang } \\
\text { dilakukan P2TP2A. }\end{array}$ & $\begin{array}{l}\text { Dalam penelitian sama- } \\
\text { sama membahas tentang } \\
\text { keadilan restoratif } \\
\text { sebagai objek kajiannya, } \\
\text { meskipun penelitian } \\
\text { terdahulu } \\
\text { mengkorelasikan dengan } \\
\text { keadilan perspektif Islam. }\end{array}$ \\
\hline 2 & $\begin{array}{lr}\text { Peran } & \text { Pusat } \\
\text { Pelayanan Terpadu } \\
\text { Pemberdayaan } \\
\text { Perempuan Dan Anak } \\
\text { (P2TP2A) Kabupaten } \\
\text { Malang } r \text { Pasca }\end{array}$ & $\begin{array}{l}\text { Dalam Penelitian terdahulu } \\
\text { memfokuskan pada bagaimana } \\
\text { bentuk, proses dan kendala- } \\
\text { kendala yang dihadapi oleh } \\
\text { P2TP2A Kabupaten Malang } \\
\text { dalam menanggulangi kasus }\end{array}$ & $\begin{array}{l}\text { Antara } r \text { penelitian } \\
\text { terdahulu dengan } \\
\text { penelitian peniliti sama- } \\
\text { sama studi empiri atau } \\
\text { field reseacrh yang } \\
\text { dilakukan di Pusat }\end{array}$ \\
\hline
\end{tabular}




\begin{tabular}{|c|c|c|c|}
\hline & $\begin{array}{l}\text { Terbitnya PERDA } \\
\text { No.3 Tahun } 2009 \\
\text { Tentang Perlindungan } \\
\text { Perempuan Dan Anak } \\
\text { Korban Kekerasan } \\
\text { yang ditulis oleh } \\
\text { Machi Ahmad. }\end{array}$ & $\begin{array}{l}\text { kekerasan dalam rumah tangga } \\
\text { dan bagaimana cara } \\
\text { mengatasinya. Sedangkan } \\
\text { perbedaanya dengan penelitian } \\
\text { peneliti, adalah fokus } \\
\text { permasalahannya lebih menitik } \\
\text { beratkan pada proses } \\
\text { rehabilitasi dan pemenuhan hak } \\
\text { korban perkosaan dalam } \\
\text { mewujudkan keadilan restoratif } \\
\text { yang dilakukan P2TP2A. }\end{array}$ & $\begin{array}{l}\text { Pelayanan } \\
\text { Pemberdayaan } \\
\text { Perempuan dan Anak } \\
\text { (P2TP2A) Kabupaten } \\
\text { Malang. }\end{array}$ \\
\hline 3 & 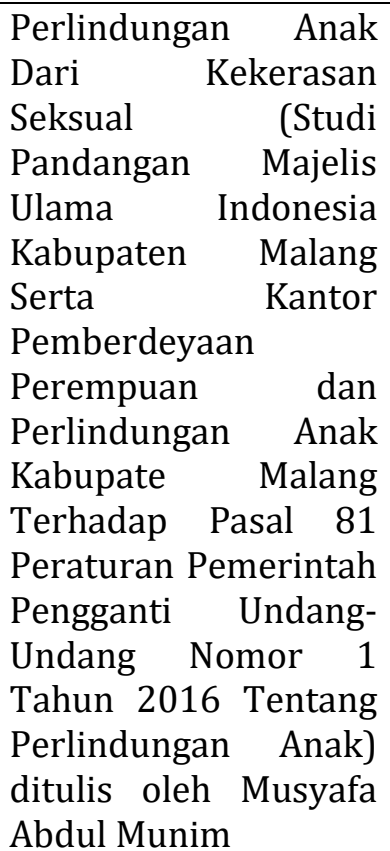 & $\begin{array}{l}\text { Penelitian ini memfokuskan } \\
\text { pada permasalahan bagaimana } \\
\text { pandangan MUI Kabupaten } \\
\text { Malang dan KP3A Kabupaten } \\
\text { Malang Terhadap hukum pelaku } \\
\text { kekerasan seksual dalam pasal } \\
81 \text { PERPU No. } 1 \text { Tahun 2016, } \\
\text { dan Bagaimana Pandangan } \\
\text { mereka terhadap hukuman yang } \\
\text { sesuai dengan bagi pelaku } \\
\text { kekerasan anak tersebut. } \\
\text { Sedangkan perbedaanya dengan } \\
\text { penelitian peneliti, adalah fokus } \\
\text { permasalahannya lebih menitik } \\
\text { beratkan pada proses } \\
\text { rehabilitasi dan pemenuhan hak } \\
\text { korban perkosaan dalam } \\
\text { mewujudkan keadilan restoratif } \\
\text { yang dilakukan P2TP2A. }\end{array}$ & 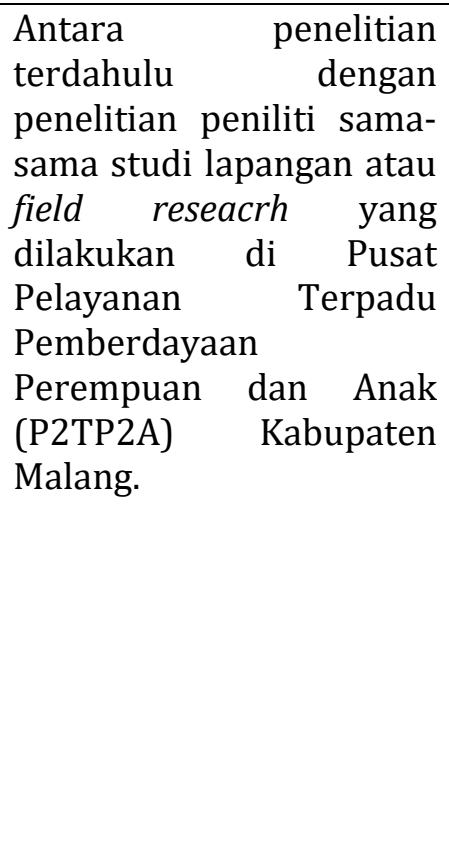 \\
\hline
\end{tabular}

\section{METODE PENELITIAN}

Penelitian ini dilakukan di Pusat Pelayanan Terpadu Pemberdayaan Perempuan dan Anak (P2TP2A), yang secara yuridis-Formal lembaga tersebut merupakan lembaga berbasis masyarakat yang dibentuk berdasarkan peraturan Bupati Malang Nomor 8 Tahun 2011. Jenis penelitian ini dikatagorikan penelitian lapangan (field research) karena mayoritas data lapangan sebagai data primer, sedangkan data pustaka normatif atau aturan tertulis dijadikan data skunder (Muhammad, 2004). Pendekatan dalam penelitian ini adalah pendekatan kualitatif.

Penelitian ini terdapat dua data, yaitu data primer dan data sekunder. Data primer penelitian ini adalah wawancara secara langsung dari beberapa konselor di lembaga P2TP2A Kabupaten Malang. Data sekunder sumber informasi selain dari sumber primer, yakni sumber sekunder menjelaskan tentang kajian teori dalam penelitian ini. Sumber data yang diperoleh dari data yang mendukung terhadap data primer seperti Peraturan Bupati Malang Nomor 8 Tahun 2011, Undang-Undang No. 23 Tahun 2002 jo Undang-Undang No. 35 Tahun 2014 tentang Perlindungan Anak, dan dokumen-dokumen tentang data kekerasan anak di Kabupaten Malang. 
Sedangakan tehnik pengumpulan data dilakukan dengan wawancara dan dokumentasi. dengan wawancara terstruktur dilakukan dengan pihak-pihak P2TP2A mengenai bagaimana proses rehabilitasi korban pemerkosaan. Dokumentasi Sejumlah besar fakta dan data tersimpan dalam bahan yang berbentuk dokumentasi, seperti surat, catatan harian, cendera mata, laporan, dan foto. Sifat utama data ini tak terbatas pada ruang dan waktu sehingga memberi peluang kepada peneliti untuk mengetahui hal-hal yang pernah terjadi waktu silam (Noor, 2012). Langkah ini digunakan sebagai pelengkap dan penunjang keontetikan data penelitian.

\section{HASIL DAN PEMBAHASAN}

\section{Proses Pendampingan Rehabilitasi Korban Perkosaan di P2TP2A}

Anak dalam visi Konvensi Hak Anak PBB merupakan sebagai suatu subjek, anak yang diposisikan sebagai manusia dan anak diakui sebagai mahluk otonom dan merdeka. Bagaimanapun juga, anak-anak adalah sesosok mahluk yang harus tetap dihormati, dilindungi dan dapat ditumbuh kembangkan karena mereka merupakan amanat Tuhan yang Maha Esa. Menurut Undang-Undang Republik Indonesia No 23 tahun 2002 jo No 35 Tahun 2014 tentang Perlindungan Anak. Anak adalah seseorang yang belum berusia 18 tahun, termasuk anak yang masih dalam kandungan.

Hak Anak pada dasarnya adalah hak azasi manusia. Dalam Konvensi Hak Anak memuat dua pasal mengenai hak-hak anak sebagai korban. Perlunya memberi perawatan khusus kepada anak telah dinyatakan dalam Dekralasi Jenewa tentang Hak-hak Anak tahun 1924, pasal 39 menjelaskan hak-hak anak korban, khususnya korban pelanggaran serius. Pasal ini menetapkan, negara-negara anggota harus mengambil langkah-langkah yang dipandang perlu untuk mendorong pemulihan fisik dan psikologi dan integrasi sosial anak korban dari segala bentuk pengabaian, eksploitasi atau abuse, penyiksaan atau bentuk-bentuk lain kekejaman, perlakuan yang tidak berprikemanusiaan dan menistakan atau konflik bersenjata. Pemulihan dan reintegrasi hendaknya terjadi di lingkungan yang menunjang kesehatan, harga diri dan martabat anak (Riyanto, n.d.).

Melihat realitas pengaturan perlindungan korban belum menampakkan pola yang jelas, dalam hukum pidana positif yang berlaku pada saat ini perlindungan korban lebih banyak merupakan "perlindungan abstrak" atau "perlindungan tidak langsung"(Gultom, 2014). Sehingga demikian, Pusat Pelayanan Terpadu Pemberdayaan Perempuan dan anak (P2TP2A) merupakan Salah satu lembaga yang berbasis masyarakat dan beranggotakan stakeholder pemerhati perempuan dan anak melakukan layanan advokasi bagi perempuan dan anak dari kelompok rentan, utamanya perempuan dan anak korban kekerasan. 
Berdasarkan informasi dari informan bahwa P2TP2A sebagai lembaga sosial yang memberikan pendampingan terhadap korban kejahatan seksual baik secara litigasi atau nonlitigasi. Khususnya pada korban kejahatan seksual, kami selalu siap-siaga dan responsif bilamana dari pihak korban atau kelurga korban mengadukan tindakan tersebut pada kami (baca: P2TP2A). Bahkan tidak jarang kami mendapatkan laporan dari orang lain atau berita, yang kemudian kami terlusuri kebenaran tersebut. Meskipun pada awalnya pihak korban sulit terbuka atau cenderung dirahasiakan, karena kejahatan seksual dianggap sebagai aib keluarga. Oleh karenanya, salah satu komitmen P2TP2A untuk melakukan pendampingan secara totalitas pada korban kejahatan seksual, karena menurut beliau kejahatan seksual terhadap anak merupakan kejahatan luar biasa yang tidak punya pri-kemanusiaan, bahkan kejahatan ini dikatagorikan sebagai pelanggaran terhadap Hak Asasi Manusia.

Para korban tindak kejahatan seksual sangat memerlukan rehabilitasi karena bagaimanapun kejadian yang menimpanya merupakan sebuah trauma, terlepas dari beberapa alasan korban dan keluarganya memilih untuk tidak menceritakan pengalaman tersebut. Dalam Undang-Undang No. 23 Tahun 2002 tentang Perlindungan Anak. Pasal 64-65 menegaskan bahwa seorang anak yang menjadi korban tindak pidana berhak mendapat rehabilitasi dari pemerintah baik secara fisik maupun secara mental, spiritual dan sosial, selain itu privasinya wajib untuk dilindungi, nama baiknya dijaga dan dipelihara, keselamatannya juga sebagai saksi korban menjadi tanggung jawab pemerintah, dan anak yang jadi korban tersebut berhak untuk senantiasa mengetahui perkembangan perkara yang dihadapinya. Begitu juga, dalam UndangUndang No. 39 Tahun 1999 tentang Hak Asasi Manusia menjelaskan bahwa rehabilitasi seharusnya diberikan kepada semua korban tindak pidana yang memerlukan pemulihan baik secara fisik maupun mental. Oleh karenanya lembaga-lembaga Perlindungan Anak (PTP2A) harus bersikap lebih aktif dalam memberikan bantuan berupa rehabilitasi korban sesuai amanat dari undang-undang.

Dari paparan di atas dapat dipahami, kekerasan seksual merupakan perbuatan disengaja yang menimbulkan kerugian atau bahaya terhadap anak-anak (baik secara fisik, psikologis maupun sosial). Meminjam istilah dari Marzuki Umar bahwa "membahas masalah seksualitas manusia ternyata tidak sederhana yang dibayangkan, atau tidak seperti yang dipahami masyarakat kebanyakan. Hal ini menunjukkan seksualitas manusia (nafsu birahi) merupakan ancaman buat manusia lainnya (predator), jika nafsu tersebut tidak bisa dikendalikan.

Pada dasarnya, Islam secara normatif mengapresiasi seksualitas sebagai fitrah manusia baik laki-laki maupun perempuan yang harus dikelola dengan sebaik-baiknya dan dengan cara yang sehat. Dalam bahasa agama seks adalah anugerah Tuhan. Hasrat seks harus dipenuhi sepanjang manusia membutuhkannya. Pengekangan atasnya bisa menimbulkan krisis psikologi 
dan sosial. Islam tidak menganjurkan selibat dan asketisme. Islam mengabsahkan hubungan seks hanya melalui proses ritual perkawinan. Islam dengan begitu tidak membenarkan promiskuitas (seks bebas), karena cara ini dipandang tidak bertanggungjawab. Islam menganggap hubungan seksual yang dilakukan diluar perkawinan dianggap ilegal dan disebut sebagai zina.

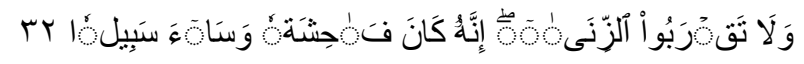

"Dan janganlah kamu mendekati zina karena itu sekeji-kejinya perbuatan" (QS Al-Isra (17): 32).

Dengan demikian, dalam hukum syariat Islam pelaku tindak kejahatan seksual terhadap anak merupakan pezina karena melakukan hubungan layaknya suami istri tanpa adanya ikatan perkawinan terlebih tindakan tersebut dilakukan secara paksa dan korbannya masih dibawah umur. Artinya, seksualitas manusia terkategori dalam dua hal, yaitu a) seksualitas yang bermoral, sebagaai seksualitas yang sehat dan baik, b) seksualitas immoral, sebagai seksualitas yang sakit dan jahat (Umar Sa'bah, 1997).

Kekerasan seksual (sexual abuse) juga, dapat dikatagorikan menjadi dua berdasarkan dari identitas pelaku, yaitu: Pertama, familial abuse merupakan sexual abuse yang masih dalam hubungan darah, menjadi bagian dalam keluarga inti. Seseorang yang menjadi pengganti orang tua. misalnya ayah tiri, atau kekasih, pengasuh atau orang yang dipercaya merawat anak, termasuk dalam dalam pengertian incest. Kedua, Extra familial Abuse adalah kekerasan yang dilakukan oleh orang lain diluar keluarga korban. Pada pola pelecehan seksual ini, pelaku biasanya orang dewasa yang dikenal oleh sang anak dan telah membangun relasi dengan anak tersebut, kemudian membujuk sang anak ke dalam situasi dimana pelecehan seksual tersebut dilakukan, sering dengan memberikan imbalan tertentu yang tidak didapatkan oleh sang anak di rumahnya (Noviana, 2015).

Kedua katagori di atas, kekerasan seksual yang memang seringkali terjadi diberbagai daerah di Indonesia. Namun, secara khusus berdasarkan informasi yang diperoleh di P2TP2A kasus pemerkosaan yang sering terjadi di kabupaten Malang merupakan tindak kejahatan Extra familial Abuse. Artinya, pelaku kejahatan seksual dilakukan oleh orang lain diluar anggota keluarga dan mempunyai relasi antara korban dan pelaku. Sehingga, tindak kejahatan seksual ini membuat korban tidak memberitahukan pada orang tuannya karena khawatir menimbulkan kemarahan, serta cacat fisik maupun psikologisnya diketahui publik.

Kekerasan seksual terhadap anak dapat dilihat dari sudut pandang biologis dan sosial, yang kesemuanya berkaitan dengan dampak psikologis pada anak. Secara biologis, sebelum pubertas, organ-organ vital anak tidak disiapkan untuk melakukan hubungan intim, apalagi untuk organ yang memang tidak ditujukan untuk hubungan intim. Jika dipaksakan, maka tindakan tersebut akan merusak jaringan. Ketika terjadi kerusakan secara fisik, maka telah 
terjadi tindak kekerasan. Sedangkan dari sudut pandang sosial, karena dorongan seksual dilampiaskan secara sembunyi-sembunyi, tentu saja pelaku tidak ingin diketahui oleh orang lain. Pelaku akan berusaha membuat anak yang menjadi sasaran 'tutup mulut'. Salah satu cara yang paling mungkin dilakukan adalah dengan melakukan intimidasi. Ketika anak diancam, maka saat itu juga secara alami tubuh anak juga melakukan pertahanan atau penolakan. Ketika secara biologis tubuh anak menolak, maka paksaan yang dilakukan oleh seorang pedophil akan semakin menimbulkan cedera dan kesakitan. Saat itu berarti terjadi kekerasan. Rasa sakit dan ancaman ini tentu saja menjadi pengalaman traumatis bagi anak. Anak akan selalu mengalami perasaan tercekam sampai ia mengatakannya. Sedangkan untuk mengatakan, anak selalu dihantui oleh intimidasi dan ancaman dari pelaku. Karena itu, rasa sakit dan intimidasi juga menjadi kekerasan psikologis bagi anak (Noviana, 2015).

Dalam kontek hukum Indonesia, tidak ada ketentuan secara khusus tentang batas umur kapan seseorang dikatagorikan sebagai dewasa. Namun dalam tiap perundang-undangan diatur kreteria tersendiri mengenai definisi Anak. Berdasarkan dari informan, mayoritas korban tindak kejahatan seksual adalah anak-anak atau antara umur 10 sampai Dengan 18 Tahun. Hal inilah yang membuat prihatin pihak P2TP2A untuk melakukan pendampingan atau rehabilitasi, agar tidak terjadi dampak yang lebih luas terhadap perkembangan psikologis anak korban kejahatan seksual atau lingkungannya. Pasal 1 ayat 2 Undang-undang No. 35 Tahun 2014 menegaskan bahwa "Perlindungan anak adalah segala kegiatan untuk menjamin dan melindungi anak dan hak-haknya agar dapat hidup, tumbuh, berkembang, dan berpartisipasi, secara optimal sesuai dengan harkat dan martabat kemanusiaan, serta mendapat perlindungan dari kekerasan dan diskriminasi". Disamping itu juga, pasal 69A Undang-Undang No. 35 Tahun 2014 menjelaskan bahwa perlindungan khusus bagi Anak korban kejahatan seksual sebagaimana dimaksud dalam Pasal 59 ayat (2) huruf j dilakukan melalui upaya; a) Edukasi tentang kesehatan reproduksi, nilai agama, dan nilai kesusilaan; b) Rehabilitasi sosial; c) Pendampingan psikososial pada saat pengobatan sampai pemulihan; dan d) Pemberian perlindungan dan pendampingan pada setiap tingkat pemeriksaan mulai dari penyidikan, penuntutan, sampai dengan pemeriksaan di sidang pengadilan.

Pasal ini lebih menekankan terhadap pentingnya rehabilitasi terhadap korban tindak kejahatan seksual karena mereka sangat memerlukan pemulihan baik secara fisik maupun mental. Dalam Undang-Undang Republik Indonesia Nomor 21 tahun 2007 tentang Pemberantasan Tindak Pidana Perdagangan Orang Pasal 1 angka 14, rehabilitasi diartikan sebagai "pemulihan dari gangguan terhadap kondisi fisik, psikis dan sosial agar dapat melaksanakan perannya kembali secara wajar baik dalam keluarga maupun dalam masyarakat.". 
Rehabilitasi diberikan agar tercapainya pemulihan yang sempurna bagi diri korban yang mengalami kekerasan seksual dan menurut pasal 35 ayat (2) Peraturan Pemerintah Republik Indonesia Nomor 40 tahun 2011 tentang Pembinaan, Pendampingan, dan Pemulihan Terhadap Anak yang menjadi Korban atau Pelaku Pornografi, Rehabilitasi Sosial diberikan dalam bentuk; a) Motivasi dan diagnosis psikososial; b) Perawatan dan pengasuhan; c) Pelatihan vokasional dan pembinaan kewirausahaan; d) Bimbingan mental spiritual; e) Bimbingan fisik; f) Bimbingan sosial dan konseling psikososial; g) Pelayanan aksesibilitas; h) Bantuan dan asistensi sosial, dan lain-lain.

Adapun proses pelaksanaan rehabilitasi mental korban tindak kejahatan seksual di P2TP2A merupakan hasil dari analisis antara teori rehabilitasi dan temuan dilapangan ketika peneliti melakukan wawacara dengan para Konselor di P2TP2A. Diantaranya sebagai berikut: Pertama, penerimaan atau penjaukauan laporan kekerasan seksual. Hal ini berkaitan dengan "Penerimaan korban tindak kejahatan seksual ada tiga yaitu korban datang kesini, pihak P2TP2A yang mengdatangi lagsung, dan dirujuk oleh instansi lain seperti kepolisian (Hikmah Bafaqih, Wawancara, 3 April, 2017). Kedua, identifikasi dan registrasi yang bertujuan untuk melengkapi data awal tentang peristiwa kekerasan seksual dan keluarga bila memungkinkan. Sedangkan registrasi merupakan proses pencatatan korban sebagai penerima layanan perlindungan dan rehabilitasi korban tindak kejahatan seksual. Ketiga, assesmen, untuk memberikan tindakan lebih lanjut terhadap korba, terlebih dahulu kami melakukan assesment agar kami bisa mengambil tindakan yang tepat bagi korban" (Halim Rosyid, Wawancara, 20 Maret 2017). Keempat, pelayana rehabilitatif yang terdiri dari; a) Pelayanan psikososial dan konseling oleh pekerja sosial dan psikologi; b) Terapi untuk penyembuhan trauma yang dilakukan oleh pekerja sosial; c) Pelayanan kunjungan rumah oleh pekerja sosial. Kelima, advokasi dan pembelan hukum, harus benar-benar dipersiapkan mentalnya ketika menghadapi masalah hukum agar proses hukum dapat berjalan dengan lancar dan anak tidak merasa trauma atau takut ketika berhadapan dengan hukum (Khoirirotin Umi Nasichah, Wawancara, 20 Maret 2017).

Disamping itu, Berdasarkan Peraturan Bupati Malang No 8 Tahun 2011, Pasal 3 P2TP2A melakukan pola pembinaan terhadap korban tindak pidana perkosaan meliputi rehabilitasi dan reitegrasi. Sebagai gambaran terhadap pengelolaan tersebut, P2TP2A melakukan langkahlangkah sebagai berikut, diantaranya; Pertama, pembinaan mental dan spritual bertujuan untuk membentengi atau memulihkan korban tindak kejahatan seksual agar mereka bisa menyadari atas realitas yang terjadi dengan lebih meningkatkan keimanan mereka pada sang khaliq. Kedua, pembinaan sosial dan psikologis sebagai salah satu upaya yang dilakukan pihak P2TP2A dalam mewujudkan keadilan dan kesetaraan gender sehigga korban tindak kejahatan seksual tidak kesulitan dalam penyesuaian diri dengan lingkungan. Ketiga, pembinaan 
keterampilan/kreasi bertujuan agar anak dapat mengembangkan potensi yang dimiliki serta bangkit dari ketidakberdayaannya sehingga dapat tumbuh sebagaimana mestinya (K.U. Nasichah, Wawancara, 20 Maret 2017).

\section{Pemenuhan Hak-Hak Korban Perkosaan yang Dilakukan Oleh Pusat Pelayanan Terpadu Pemberdayaan Perempuan dan Anak (P2TP2A) Dalam Mewujudkan Keadilan Restoratif}

Munculnya PERPU dianggap sebagai upaya pembaharuan hukum terhadap tindak kejahatan perkosaan pada anak melalui pencantuman sanksi kebiri sebagai alternatif sanksi pidana. Sanksi kebiri pada pelaku kejahatan kesusilaan ini diharapkan mampu memberikan efek jera bagi pelaku sekaligus bisa memberikan keadilan yang setimpal bagi anak sebagai korban terhadap apa yang dilakukan oleh pelaku kejahatan kesusilaan tersebut. Namun banyak kalangan yang tidak sepakat dengan sanksi tersebut, karena dirasa bertentangan dengan Hak Asasi Manusia (HAM). Seharusnya pemerintah mengakomodir hukuman tambahan dalam bentuk "Reparasi kepada Korban dan Perawatan Psikologis pada Pelaku" sehingga dapat memberikan pemulihan hak-hak korban secara total. Artinya, pemerintah memberikan layanan medis, layanan psikologis pada korban yang ditujukan untuk memulihkan hak-haknya yang hilang. Perawatan psikologis juga pada pelaku penting diberikan, agar pelaku sembuh dan tidak melakukan kejahatan seksual lainnya. Pemulihan psikologis ini harus diberikan selama pelaku menjalani hukuman (Supriyadi Widodo Eddyono, Ahmad Sofian, \& Anugerah Rizki Akbari, 2016).

Menurut pihak P2TP2A, jika tindak kejahatan seksual atau perkosaan hanya mengandalkan pada hukum positif sebagai penyelesaiannya maka pihak korban perkosaan belum mendapatkan aspek manfaatnya terhadap penerapan hukum tersebut. Karena akibat tindak kejahatan tersebut, secara sosiologis dan psikologis pihak korban perkosaan adalah orang yang paling dirugikan sepanjang hidupnya, khususnya dalam pemulihan hak-haknya yang hilang. Dalam prinsip dasar Konvensi Hak-Hak Anak telah dijelaskan, meliputi; (1) Non diskriminasi; (2) Kepentingan yang terbaik bagi anak; (3) Hak untuk hidup, kelangsungan hidup, dan perkembangan; (4) Penghargaan terhadap pendapat anak.

Menurut peneliti, tindak kejahatan seksual atau perkosaan terhadap anak sudah bertentangan dengan prinsip dasar konvensi hak-hak anak khususnya dalam hak dasar anak (hak untuk hidup, kelangsungan hidup dan berkembang). Secara sosiologis dan psikologis anak yang mengalami perkosaan berbeda dengan yang tidak mengalami kekerasan seksual atau perkosaan. Hal ini disebabkan dampak dari rasa traumatik yang ditanggung seumur hidup oleh korban. Pendampingan dan perlindungan hukum pada hakikatnya tidak akan mengembalikan hak-hak korban yang sudah. 
Berkaitan dengan hal diatas, pemerintah melalui Undang-Undang Nomor 35 Tahun 2014 Tentang Perubahan Atas Undang-Undang Nomor 23 Tahun 2002 Tentang Perlindungan Anak secara substansial telah memberikan perlindungan khusus serta cakupan hak-hak terhadap anak korban kejahatan seksual, yang termuat dalam Pasal 69A, yaitu sebagai berikut: Perlindungan khusus bagi anak korban kejahatan seksual sebagaimana dimaksud dalam Pasal 59 ayat (2) huruf j dilakukan melalui upaya; a) Edukasi tentang kesehatan reproduksi, nilai agama, dan nilai kesusilaan; b) Rehabilitasi sosial; c) Pendampingan psikososial pada saat pengobatan sampai pemulihan;dan d) Pemberian perlindungan dan pendampingan pada setiap tingkat pemeriksaan mulai dari penyidikan, penuntutan, sampai dengan pemeriksaan di setiap pengadilan.

Untuk Pemerintah Kabupaten Malang berdasarkan Peraturan Daerah Kabupaten Malang Nomor 11 Tahun 2013 Tentang Penyelenggaraan Pemenuhan Anak, pasal 1 ayat 6 dan 7 menjelaskan hak anak dan pemenuhan hak anak adalah "bagian dari hak asasi manusia yang wajib dijamin, dilindungi dan dipenuhi oleh orang tua, keluarga, masyarakat, Pemerintah Daerah, Pemerintah dan Negara" dan "Pemunuhan Hak Anak adalah segala kegiatan untuk menjamin dan melindungi anak serta hak-haknya agar dapat hidup, tumbuh, berkembang dan berpartisipasi, secara optimal sesuai dengan harkat dan martabat kemanusiaan serta mendapat perlindungan dari kekerasan dan diskriminasi".

Sebab itulah, dalam rangka mewujudkan keadilan restoratif pada korban perkosaan pihak P2TP2A melakukan beberapa aspek manfaat dalam rangka untuk memberikan hak-hak yang hilang terhadap korban tindak kejahatan perkosaan, meliputi: 1) Aspek pencegahan atau preventif, hal ini menunjukkan bagaimana keluarga, masyarakat dan negara mempunyai andil dalam membangun sinergitas untuk melakukan pencegahan timbulnya masalah kejahatan seksual atau perkosaan. 2) Aspek Litigasi: upaya hukum yang dilakukan pihak P2TP2A terhadap korban dalam proses dipengadilan. 3) Aspek Terapi yang bertujuan untuk mengurangi bahkan dimungkinkan untuk menghilangkan penderitaannya. 4) Aspek Rehabilitasi sebagai usaha untuk memperoleh fungsi dan penyesuaian diri secara maksimal dan untuk mempersiapkan korban secara fisik, mental dan sosial dalam kehidupannya dimasa mendatang. Tidak hanya korban yang seharusnya direhabilitasi, akan tetapi juga pada pelaku agar tidak berdampak terhadap kejahatan yang lebih luas lagi. Meskipun dalam prakteknya hal itu (rehabiltasi terhadap pelaku) tidak pernah dilakukan karena berbagai persoalan dan peraturan yang ada (H. Bafaqih, Wawancara, 3 April, 2017).

Bedasarkan paparan di atas, dapat dipahami upaya P2TP2A dalam mewujudkan keadilan restoratif terhadap korban perkosaan, tidak terlapas dari amanah peraturan perundang-undangan. Artinya, perlindungan anak secara nasional telah memperoleh pijakan yuridis diantaranya Undang-Undang Dasar 1945 sebagai landasan konstitusional, Undang- 
Undang No. 39 Tahun 1999 Tentang Hak Asasi Manusia, Undang-Undang No. 31 Tahun 2014 Perubahan atas Undang-Undang 13 Tahun 2006 Tentang Perlindungan Saksi dan Korban, Undang-Undang No. 35 Tahun 2014 Perubahan atas Undang-Undang 23 Tahun 2002 Tentang Perlindungan Anak, yang menegaskan bahwa korban tindak kejahatan perkosaan berhak mendapatkan rehabilitasi baik fisik, mental, spiritual dan sosial. Melihat dari tugas, fungsi dan kedudukan P2TP2A yang telah dibentuk oleh Peraturan Bupati No. 8 Tahun 2011 tentang Organisasi dan Tata Kerja Pusat Pelayanan Terpadu Pemberdayaan Perempuan dan Anak (P2TP2A) Kabupaten Malang Pasal 7 menerangkan bahwa P2TP2A mempunyai tugas memberikan pelayan fisik, psikis, pendampingan hukum, rehabilitasi sosial, reintegrasi, fasilitasi pemberdayaan ekonomi, pusat informasi, rujukan, konsultasi, advokasi, pendidikan dan pelatihan serta membantu penyelesaian permasalahan kekerasan pada perempuan dan anak. Dengan demikian, sudah menjadi kewajiban P2TP2A untuk memberikan pelayanan sesuai dengan peraturan perundang-undangan yang berlaku bagi korban perkosaan.

Selain yang telah disebutkan di atas, sudah menjadi Hak Korban dan kewajiban P2TP2A untuk identitas korban atau privasinya wajib untuk dilindungi agar menimbulkan suatu penilaian dari masyarakat terhadap anak korban perkosaan. Ketika nama anak tidak dirahasiakan sebagai salah satu korban perkosaan, maka pandangan masyarakat terhadap si Anak akan berubah drastis. Tidak jarang stigmatisasi masyarakat terhadap korban perkosaan sebagai orang yang kotor. Hal ini terbukti ketika peneliti ingin mewawancarai korban perkosaan, pihak P2TP2A tidak memperbolehkan dengan alasan identitas korban dirahasiakan untuk publik.

Berdasarkan hal tersebut, memperbaiki/memulihkan kondisi atau keadaan yang rusak sebagai akibat terjadinya tindak kejahatan baik korban, pelaku dan masyarakat menjadi keharusan dalam kontek keadilan restoratif. Hal ini didasarkan pada pemikiran bahwa keadilan restoratif adalah suatu pendekatan untuk memecahkan masalah kejahatan di antara para pihak, yaitu korban, pelaku, dan masyarakat, dalam suatu relasi yang aktif dengan aparat penegak hukum. Sebab itu, dalam memecahkan masalah kejahatan tersebut, keadilan restoratif mempergunakan asumsi-asumsi sebagai berikut; a) Sumber dari kejahatan adalah kondisi dan relasi sosial dalam masyarakat; b) Pencegahan kejahatan tergantung pada tanggung jawab masyarakat (termasuk pemerintah lokal dan pemerintah pusat dalam kaitannya dengan kebijakan sosial pada umumnya) untuk menangani kondisi-kondisi sosial yang dapat menyebabkan terjadinya kejahatan; c) Kepentingan para pihak dalam penyelesaian kasus kejahatan tidak dapat diakomodasi tanpa disediakannya fasilitas untuk terjadinya keterlibatan secara personal; d) Ukuran keadilan harus bersifat fleksibel untuk merespon fakta-fakta penting, kebutuhan personal, dan penyelesaian dalam setiap kasus; e) Kerjasama di antara aparat penegak hukum serta antara aparat dengan masyarakat dianggap penting untuk 
mengoptimalkan efektifitas dan efisiensi cara penyelesaian kasusnya; f) Keadilan dicapai dengan prinsip keseimbangan kepentingan di antara para pihak (Widiartana, 2011).

Dengan demikian, bisa dikatakan bahwa keadilan restoratif sebagai upaya pengayoman terhadap hak asasi manusia (HAM), yang secara filosofis upaya perbaikan / penyembuhan tersebut dilakukan tidak dengan melihat ke belakang sebagai dasar pembenarannya. Restorasi / perbaikan / penyembuhan tersebut dilakukan agar dimasa yang akan datang dapat terbangun suatu masyarakat yang lebih baik. Keadilan restoratif pada prinsipnya merupakan suatu pendekatan untuk melakukan respon secara sistematik terhadap tindak pidana yang terjadi dengan fokus utama untuk memperbaiki kerusakan/memulihkan penderitaan yang ditimbulkan oleh tindak pidana tersebut tanpa meninggalkan perhatian yang seimbang antara kepentingan korban, pelaku dan masyarakat. Prinsip-prinsip keadilan restoratif tersebut, juga menunjukkan bahwa sanksi/bentuk pertanggungjawaban pelaku yang berorientasi pada pemulihan/rehabilitasi atas penderitaan/kerugian korban akibat dari tindak kejahatan perkosaan lebih mendapatkan tempat dalam pandangan keadilan restoratif, serta adanya prinsip-prinsip keadilan yang berlaku dalam masyarakat sebagaimana terkandung dalam Pancasila.

\section{KESIMPULAN}

Dari penelitian ini, peneliti dapat mengambil kesimpulan sebagai berikut, bahwa; pertama, proses pendampingan rehabilitasi korban perkosaan yang dilakukan oleh Pusat Pelayanan Terpadu Pemberdayaan Perempuan dan Anak (P2TP2A) di Kabupaten Malang. Pertama, penerimaan atau pengajuan laporan kekerasan seksual sebagai tahap awal dalam kegiatan pelayanan perlindungan terhadap korban perkosaan atau kekerasan seksual. Kedua, Indentifikasi dan Registrasi yang bertujuan untuk proses data awal tentang korban perkosaan dan juga data base lembaga P2TP2A. Ketiga, Assesmen untuk menelaah situasi kehidupan anak, keluarga dan lingkungan. Keempat, Pelayanan Rehabilitasi sebagai tindakan setelah dilakukannya assesmen, sehingga penanganan rehabilitasinya sesuai dengan kondisi korban. Kelima, Advokasi dan Pembelaan Hukum sebagai perlindungan hukum terhadap korban dalam memperoleh keadilan dalam aspek legalitas. Disamping itu, pihak P2TP2A melakukan pembinaan terhadap korban perkosaan dengan langkah, pembinaan mental dan spiritual, pembinaan Sosial dan Psikologis serta pembinaan Kerampilan/kreatifitas.

Kedua, dalam upaya mewujudkan keadilan restoratif terhadap korban perkosaan Pusat Pelayanan Terpadu Pemberdayaan Perempuan dan Anak (P2TP2A), tidak hanya mangandalkan pendampingan hukum positif sebagai kemaslahatan pada korbaan perkosaan, akan tetapi secara khusus pihak P2TP2A menitik beratkan pada pemulihan hak-hak korban perkosaan yang hilang seperti hak mendapatkan perlindungan, hak tumbuh kembang, dan hak mendapatkan 
pendidikan pada beberapa aspek yaitu: aspek Pencegahan atau Preventif, aspek Litigasi, aspek terapi, dan aspek rehabilitasi.

\section{DAFTAR PUSTAKA}

Aini, N. (2009). Logika adversarial penegakan hukum kekerasan terhadap perempuan (analisis hukum berperspektif feminis). Syariah: Jurnal Ilmu Hukum, 9(2), 1-18.

Fakih, M. (1996). Analisis gender dan transformasi sosial. Yogyakarta : Pustaka Pelajar.

Gultom, M. (2014). Perlindungan hukum terhadap anak dan perempuan. Bandung: Refika Aditama.

Muhammad, A. (2004). Hukum dan penelitian hukum. Citra Aditya Bakti.

Noor, J. (2012). Metodologi penelitian: Skripsi, tesis, disertasi, dan karya Ilmiah. Jakarta: Kencana Prenada Media Group.

Noviana, I. (2015). Kekerasan seksual terhadap anak: Dampak dan penanganannya (Child sexual abuse: Impact and hendling). Sosio Informa, 1(1), 1-28.

Riyanto, A. (n.d.). Perlindungan anak: Sebuah buku panduan bagi Anggota Dewan Perwakilan rakyat. Jakarta: Optima.

Sari, K. (2013). Dampak psikologis terhadap pemerkosaan remaja di KabupatenTemanggung. Universitas Negeri Semarang. Retrieved from http://lib.unnes.ac.id/18522/

Supriyadi Widodo Eddyono, Ahmad Sofian, \& Anugerah Rizki Akbari. (2016). Menguji euforia kebiri: Catatan kritis atas rencana kebijakan Kebiri (chemical castration) bagi pelaku kejahatan seksual anak di Indonesia. Jakarta: Institute for Criminal Justice Reform.

Umar Sa'bah, M. (1997). Seks \& Kita. Jakarta: Gema Insani Press.

Widiartana, G. (2011, March 18). Ide keadilan restoratif pada kebijakan penanggulangan kekerasan dalam rumah tangga dengan hukum pidana. Universitas Diponegoro. 